\title{
Relationship between Personality and Biological Reactivity to Stress: A Review
}

\author{
Omid Soliemanifar ${ }^{1}$, Arman Soleymanifar $^{2}$, and Reza Afrisham ${ }^{3} \bowtie$ \\ ${ }^{1}$ General Department of Education in Khuzestan Province, Department of Education in the City of Khorramshahr, Khorramshahr, Iran \\ ${ }^{2}$ Department of Biochemistry, Metabolic Disorders Research Center, School of Medicine, Golestan University of Medical Sciences, Gorgan, Iran \\ ${ }^{3}$ Department of Clinical Biochemistry, Faculty of Medicine, Tehran University of Medical Sciences, Tehran, Iran
}

\begin{abstract}
Objective Personality traits can be the basis for individual differences in the biological response of stress. To date, many psychobiological studies have been conducted to clarify the relationship between personality and biological reactivity to stress. This review summarizes the most important findings in this area of research.

Results Key findings related to the relationship between personality factors and stress-sensitive biological systems in four research models have been summarized; model of psychosocial characteristics, model based on Rumination and Emotional Inhibition, Eysenck's biopsychological model, and Five-Factor Approach of Personality.

Conclusion According to the results of this review, it can be concluded that personality typology of individuals influenced their biological reactivity to stressful events. Understanding the biological basis of personality can help to better understand vulnerability to stress. Future research can be continuing based on framework of the four models.

Psychiatry Investig 2018;15(12):1100-1114
\end{abstract}

Key Words Personality, Psychological stress, Biological markers, Cortisol, Alpha-amylase, Immunoglobulin A.

\section{INTRODUCTION}

The term of stress was used for the first time since the seventeenth century to describe the sadness, suppression, inconvenience and disaster. However, this term was reformed in the nineteenth century, and had meaning a strong effect exerted on a person or on a physical object. ${ }^{1}$ At present, stress is a universal phenomenon and it is the result of positive and negative experiences of life. ${ }^{2}$

It is a common observation that people are clearly diverse in their psychological and physiological responses to stressors and challenging environments. ${ }^{3,4}$ Personality may be an important factor explaining this diversity, as it can have an effect on a person's assessment and perception of a potentially stressful situation and a subsequent potentially diverse biological reaction. ${ }^{5,6}$ Personality provides an important biologi-

Received: July 5, 2018 Revised: August 20, 2018

Accepted: October 14, 2018

$\triangle$ Correspondence: Reza Afrisham, PhD

Department of Clinical Biochemistry, Faculty of Medicine, Tehran University of Medical Sciences, Qods St, Taleghani Ave, Tehran, Iran

Tel: +98-9169396300, Fax: +98-21 641 95 37, E-mail: rezaafrisham@yahoo.com

(a) This is an Open Access article distributed under the terms of the Creative Commons Attribution Non-Commercial License (http://creativecommons.org/licenses/bync/4.0) which permits unrestricted non-commercial use, distribution, and reproduction in any medium, provided the original work is properly cited. cal trait, because of its hereditary bases, as well as linkage with intraindividual compatibility. ${ }^{7}$ Thus, identifying and targeting sources of individual differences, such as personality traits, which may lead to exhibiting excessive biological responses, can have important health implications. In this review, we tried to summarize evidence that the difference in biological reactivity of individuals to stress can be explained in terms of personality.

\section{The concept of stress}

The concept of stress undoubtedly owes to the works of Hans Selye, who is the father of stress research. ${ }^{8}$ In the biological field, he has defined the stress as a nonspecific and predictable response of the body to any demand. ${ }^{9}$ Actually, stress experience includes psychological and physical components, and it depends on the person perception of its controllability and predictability. ${ }^{10}$ Stress is a normal reaction and sometimes it can be useful, because of that, it provides the vital motivation and power to help person to overcome conditions such as work deadlines or exams. However, stress can become problematic when environmental demands go beyond the individual's ability to cope. ${ }^{11}$ 


\section{Theoretical models of stress}

Several models or theories within the literature have developed different scientific definitions of stress that include the basis for understanding stress. These models focus on the specific relationship between external demands, bodily processes and psychological components. Furthermore, these theoretical models help in identifying the stressful factors in a special situation as well as predicting the probability of a person's adaptation to a stressful condition. The most important of theoretical approaches of stress include; Response-based, Stimulus-based, and Transaction-Based. ${ }^{1,12}$ The following briefly are discussed each of these models.

Response-based model emphasize a reaction or a physiological response pattern. The formulation of stress as a response has been described by Hans Selye. ${ }^{13}$ He presented these reactions in "General Adaptation Syndrome (GAS) model." ${ }^{14}$ According to GAS model, a stressful event leads to a three-stage bodily response: the alert reaction stage (or physiological and psychological changes to protect against the threats), the resistance stage (or a period of optimal adaptation) and exhaustion stage which comes up with prolonged exposure to stress, and often has negative consequences such as illness, fatigue, and burnout. ${ }^{12,15}$

In the stimulus approach, stress arises from the individual's environment, and the reaction to external stressors is called "stress." Therefore, the advocates of this approach have tried to identify the stressful situations or events of life and determine ways to cope with it. ${ }^{16,17}$ This theory states that both positive and negative situations of life are considered as a stressful factor. $^{16}$

Based on the transactional model, stress is considered as a process and the interpretation of stressful events is more important than the events. ${ }^{18,19}$ In the transactional models, the stimulus or stressor, the person's response (signs and symptoms of stress) and interfering factors such as personality traits have been considered. In essence, person is seen as an active element in stressful conditions, so that the cognitive, behavioral, and emotional self-regulations affect the strategies of coping with stressors. ${ }^{20}$

\section{Aspects and measurement of stress}

According to the cognitive activation theory of stress (CATS), the term of stress is defined by four aspects that including stimuli, stress experience, response and feedback, which may be individually measured. ${ }^{21}$ The stress stimuli or stressors are threats and demands in the face of any given situation. ${ }^{13}$ Stress experience is conceptualized as individual appraisal (Perception) of the stressor or situation, so that it determines that the situation may be a threatening or pleasant stimulus. ${ }^{22}$ The stress response is a general and non-specific alarm that pro- ducing a general increase in brain arousal (neurophysiological activation) and wakefulness, and specific responses to deal the stressor events. Finally, the feedback from the stress response involves all changes resulting from wakefulness and increases arousal after a stressful situation, and plays an important role in how stress experience..$^{21,22}$

Each of these four aspects of stress actually provides four ways to measurement of stress. ${ }^{21}$ The first aspect or "stressor" is an easy way to measuring stress, and is often considered as the most objective way of measurement. Although, this method is easy to quantify external factors, but it is emotional and social factors that may determine survival in severe environments. ${ }^{23}$ The second aspect or the experience (feeling) of stress is possibly related more to research on work- related stress. ${ }^{21}$ Generally in this method, stress assessment is performed by means of questionnaires such as perceived stress scale, ${ }^{24}$ job stress, ${ }^{25}$ academic stress, ${ }^{26,27}$ etc. So that, by formulating the questions in this way, asking whether a certain situation or relationship is a source of stress. The final result of the evaluation is based on the expectancies of individual for this or similar conditions.

The stress responses (or third aspect) are the easiest way to measure the stress. Arousal affects almost all physiological systems. During the stressors, stress-sensitive physiological systems including the hypothalamic-pituitary-adrenal axis, the autonomic nervous system, and the immune system, are undergone biochemical and pathological changes. These changes are commonly shown by stress biomarkers (cortisol, alpha-amylase, pro-inflammatory cytokines, $\operatorname{IgA}),{ }^{28}$ so that alterations in basal activity and stress-dependent reactivity can be measured in these systems. ${ }^{29}$ On this way, there are different measurement methods such as psycho-endocrinology, psycho-immunology, psychophysiology, and brain biochemistry. Finally, Fourth aspect of stress or the feedback is used in many of the questionnaires in research on humans. ${ }^{21}$ This aspect is an important component of questionnaires in case of health complaints, ${ }^{30}$ and many anxiety scales. ${ }^{31}$

\section{Stress-sensitive biological systems and their biomarkers}

In the field of the physiology of stress, when the body is excited, two primary systems are activated in stress-related conditions which are hypothalamus-pituitary-adrenocortical axis (HPA) and the sympathetic-adrenal-medullary (SAM) system. ${ }^{5}$ These two systems closely interact with the immune system. ${ }^{28}$ Actually, stress can also suppress the production of immunoglobulin by reducing the function of the immune system. ${ }^{29}$ These three systems are recognized as stress-sensitive biological systems ${ }^{28}$ and they are implicated in the physiological response to stress. ${ }^{32}$ One of the methods for evaluating the activity of these three systems is using of the secretion pattern of 
specific stress-related biomarkers. ${ }^{33}$ Stress biomarkers provide an accurate, reliable and objective assessment of stress, while psychometric evaluation using stress questionnaires is highly the results of subjective responses. ${ }^{34,35}$

Biomarkers are biological indicators (as a biological characteristic) which can be objectively measured and evaluated in tissues, cells or various fluids of the body such as blood, urine and saliva. Also they represent underlying and various physiological processes, including normal biological processes, pathogenic status and/ or response to therapy. ${ }^{36,37}$ Cortisol and catecholamines (norepinephrine and epinephrine) are known as reliable stress markers for the reactivity of HPA axis and SAM systems. ${ }^{35}$ In general, serum, urine and saliva cortisol are classical biomarkers to measure of biological stress response. ${ }^{5}$ So far, the evaluation of the SAM system has been limited to electrophysiological measurements such as skin conduction, heart rate, or plasma measurements of epinephrine and norepinephrine. ${ }^{38}$ However, a rapidly growing collection of research emphasize the usefulness of salivary alphaamylase protein as an indicator of the increased activation of the SAM system..$^{28,32,33,39}$ In summary, increased cortisol secretion is due to the activation of HPA, while activation of SAM leads to an increase in sAA..$^{40,41}$

Immune system accompanied by the HPA axis and SAM as an evolutionary physiological reaction, are necessary for biological response to stressful situations. ${ }^{32,42}$ Stress-related immune changes have been investigated by various immune parameters including cytokines, C-reactive protein (CRP), ${ }^{28}$ serum immunoglobulins, complement proteins as well as immune cells. ${ }^{42,43}$ However, the salivary immunoglobulin A (sIgA) has been used as a sensitive and non-invasive biomarker for evaluating stress-induced immune system changes. The IgA is the major antibody in mucosal membrane which protects against infectious agents, allergy, and external proteins. The immune factor has a concentration that can be affected by stressful stimuli. ${ }^{29,44}$ So that the animal studies have also shown that long-term stress and acute stress reduce IgA levels. ${ }^{45}$

Evidences also suggest that biological stress response is tracked by levels of sex hormones specifically stress-related testosterone which may be a stress-sensitive biomarker. ${ }^{46}$ For example, lower levels of blood testosterone ${ }^{47}$ and suppressing steroidogenesis in testicles ${ }^{48}$ have been observed under chronic stress. Moreover, the increased levels of salivary testosterone in male students under exam stress ${ }^{5}$ and psychosocial stressors, ${ }^{49,50}$ as well as low levels of serum testosterone during anticipatory stress, ${ }^{51}$ immobilization stress (in adult male rats), ${ }^{52}$ physical stress, psychological stress, and actual stress ${ }^{53}$ have been reported. Testosterone can be a useful and sensitive biomarker for the activity of the Hypothalamic-Pituitary-Gonad axis under stress. ${ }^{54}$ Studies also showed that the HPG axis in- teracts with the HPA axis as well as the immune system in response to stress. ${ }^{47,54-56}$

\section{Personality: definition, measurement}

Personality is defined by tendencies and sustainability characteristics that determines the similarities and differences in psychological behaviors (such as thoughts, emotions, and actions) of individuals and shapes a complex pattern of learning and biological preparation. ${ }^{57}$ So far, various perspectives have been presented in the field of personality psychology. From among these perspectives, traits theory is commonly considered as an important approach to the study of human personality, which it has provided group evaluation methods in personality assessment. ${ }^{58}$ Trait-based perspectives such as the 16-factor theory of Cattell, the three-factor model of the Eysencks, and, finally, the five-factor approach of personality have made remarkable progress in theories and methods of personality assessment. ${ }^{59}$ The two personality theories are including one the five-factor model of personality that uses the NEO-Personality Inventory (NEO-PI) as a measurement instrument, ${ }^{60}$ and the other psychobiological theory of personality, which uses the Eysenck Personality Questionnaire and Temperament and Character Inventory as measurement instruments. ${ }^{6,61,62}$ Among objective personality tests, the dimensions of the big five personality (for example, neuroticism, extraversion, openness to experience, agreeableness, and conscientiousness) have received more attention than other personality constructs. ${ }^{63}$ This may be due to the fact that during the 50 years of personality research there was a common agreement that the personality could be summarized in five dimensions, which became known as the "Big Five personality." ${ }^{64}$

\section{Personality traits and coping with stress}

In health psychology, there is a growing interest about the personality traits that may be important as sources of stress. ${ }^{65}$ Personality factors play an important role in identifying, responding, and approaching stressful events. ${ }^{66}$ In fact, vulnerability to stress is based on person's appraisal and response to stressful situations. ${ }^{67}$ Types of personality can have powerful traits, which over time show resilience to stress and psychological support against the toughest of life events. ${ }^{66}$ Personality traits can predispose individuals to some mental disorders. ${ }^{68,69}$ Even animal studies also showed that personality dimensions can make them vulnerable to environmental stress. ${ }^{70,71}$ In previous studies, a number of constructs, such as hardiness, ${ }^{72}$ selfefficacy, ${ }^{73}$ optimism, ${ }^{74}$ learned Resourcefulness, ${ }^{75}$ hope,${ }^{76}$ and Sense of Coherence ${ }^{77}$ have been designed to act as personality aspects that predict positive appraisal, resilience, effective coping, or even growth in the stress process. Available evidences support the hypothesis that personality factors rather than 
the environment play a causal role in the coping and generation of a reaction to stress. ${ }^{78,79}$ So far, numerous studies have been conducted to identify the personality characteristics that influence the relationship between stimuli and stress responses. ${ }^{80}$ Several studies have shown that some personality traits can predict the level of stress as shown in the literature. For example, based on the Five-Factor Model of Personality, there was a positive correlation between the trait of neuroticism with level of psychological stress. ${ }^{81-83}$ Also, neuroticism and extraversion influenced post-traumatic stress disorder. ${ }^{84}$ type of personality combining low levels of neuroticism and high conscientiousness, have shown a favorable personality profile to the coping with stress. ${ }^{83}$ Similarly, In the case of children, neuroticism also was positively related to the level of stress. ${ }^{85}$ Furthermore, personality domains of the Temperament and Character Inventory (TCI) such as harm avoidance were positively correlated with perceived stress, but the persistence and self-directedness had a negative relationship. ${ }^{6}$ Dimensions of harm avoidance, reward dependence, and self-directedness significantly predicted by Ways of Coping scales. ${ }^{86}$ Other traits such as irritability detachment, psychasthenia and somatic anxiety, extraversion and lie scale were significant explanatory variables of reactivity to stress. ${ }^{67,87,88}$ Therefore, personality traits can be predicting the level of psychological stress in individuals, as noted. What emerges from these studies is that neuroticism is a prominent factor of personality in the reactivity to stress. However, some studies have shown that the level of psychological stress is not influenced by personality. ${ }^{80}$

\section{Personality and biological stress reactivity}

Individual differences in biological and cognitive responses to stress indicate that physiological mechanisms are influenced by moderator variables. Personality has been proposed as one of these moderators. ${ }^{89}$ So far, the impact of personality on biological stress reactivity by the biomarkers of stress-sensitive biological systems such as the hypothalamus-pituitaryadrenal (HPA), as indexed by cortisol, ${ }^{41,90}$ the sympatheticadrenal-medulla system (SAM), as indexed by cardiovascular activity, ${ }^{3}$ immune system, as indexed by $\operatorname{IgA},{ }^{29}$ sympathetic nervous system (SNS), as indexed by salivary A-amylase, ${ }^{39,40}$ sex hormones, as indexed by testosterone levels ${ }^{5}$ has been investigated. In this line of researches, several studies tried to uncover the possible associations between biological stress responses and personality. In the following, briefly, the results of these studies are presented in four models; Model of psychosocial characteristics, Model based on Rumination and Emotional Inhibition, Eysenck's biopsychological model, and five personality factors.

\section{Psychosocial characteristics and biological responses to stress}

In this field, earlier studies have attempted to discover the possible relationship between biological responses to stress, specifically cortisol and cardiovascular reactions, with psychosocial characteristics. For example, in response to stressful situation, self-esteem negatively were associated with cortisol and adrenocorticotropic hormone responses, ${ }^{91}$ instead, in other study, it has been reported that higher basal plasma cortisol levels predicted by high self-esteem, hardiness and affective stability. ${ }^{92}$ In addition, low levels of hardiness predict cardiovascular disease. ${ }^{93}$ Also, self-concept, social resonance, and trustfulness negatively predicted cortisol responses. ${ }^{94}$ In a study, morning cortisol levels related to less depressive and neurotic tendencies in men, ${ }^{95}$ and in people with lower perceived sense of control (mastery) have shown lower level of basal and/or provoked adrenocortical activity, while the high level of basal and/or lower adrenocortical reactivity predicted by monotony avoidance. ${ }^{96}$ Furthermore, available evidences showed that hostility and locus of control were associated with more cortisol and cardiovascular reactions to stress. ${ }^{90,97}$ It has been reported that individuals with lower cortisol response had higher Achievement Motivation and social acceptance. ${ }^{98}$ On the other hand, cortisol reactivity was predicted by Purpose in Life and Self-Perception in a negative direction. ${ }^{99}$ Hopelessness also was associated with a higher cortisolawakening response. ${ }^{100}$ Recently, studies reported a negative correlation between aggression control and salivary cortisol, ${ }^{101}$ and a positive correlation with salivary testosterone under psychological stress. ${ }^{5}$

\section{Model based on rumination and emotional inhibition of the biological reactivity}

Some researchers by examining previous findings have argued that these personality constructs used in early studies, have made a little progress in the field of stress studies. They proposed another model based on rumination and emotional inhibition. ${ }^{89,102}$ In general, in response to emotional stress, emotional inhibition is related to dysfunctional bodily reactions such as physiological, endocrinological, and immunological changes. ${ }^{103}$ Previous studies have shown that emotional inhibition was associated with prolonging the physiological activity ${ }^{89,104}$ lower cardiovascular recovery, ${ }^{105}$ higher cardiovascular reactivity, ${ }^{106}$ increased levels of arousal, norepinephrine, and salivary cortisol, ${ }^{103}$ as well as it can positively predict levels of salivary immunoglobulin $\mathrm{A}(\operatorname{IgA})^{29}$ and salivary testosterone ${ }^{5}$ under psychological stress. However, in a study, only the Benign Control (scale of the ECQ) and rumination were linked to heart-rate recovery. ${ }^{107}$ Rumination can lead to persistent activation of the HPA axis. ${ }^{108}$ Specifically, rumina- 
tion is correlated with high cortisol stress response. ${ }^{89}$ More recent researches also show that greater rumination on stressful situations predict the levels of salivary alpha-amylase, ${ }^{39}$ higher cortisol reactivity, ${ }^{41,108-110}$ and prolonged cardiovascular activity. ${ }^{111}$ Although, some studies have reported that there was no difference between high and low ruminators in neuroendocrine response to stress. ${ }^{112}$ Nevertheless, these disparate results may be due to the different measurements of rumination (state and trait measures). So that, the state measures of rumination may be more related to the of HPA axis activation. ${ }^{108,113}$ It is also observed co-rumination in young women's friendships (as psychological stressor) can predict increased cortisol and sAA. ${ }^{114}$

\section{Eysenck's biopsychological theory of personality}

Based on Hans Eysenck's theory, there is a biological basis to personality, and Personality differences arise from genetic heritage. $^{62,115}$ The Eysenck's model has three super-factors that are independent constructs: extraversion, neuroticism and Psychoticism. Eysenck believed that distinct physiological substrates may form the basis of the personality traits, so that characterized by differential biological responses. ${ }^{116}$ It is assumed that neuroticism is based on low activation thresholds in the sympathetic nervous system, or visceral brain. Therefore, higher score in neuroticism strongly linked with physiological responses to stress. In contrast, extraverts have high thresholds in the ascending reticular activating systems (ARAS), and other arousal systems such as the pituitary-adrenocortical system. Also, by observing the fact that the criminals were mainly male, Eysenck suggested that biological basis of psychoticism may be related to androgen (e.g., the increased testosterone levels). ${ }^{116-118}$ Several psychophysiological studies provided support for this model. Extraverts had higher arousal thresholds in react to the varying stimulations, ${ }^{117-122}$ Whereas, high neuroticism had lowest thresholds ${ }^{123}$ and it was correlated with functioning of several emotion processing networks in the brain (cortical regions that involved in emotion regulation, anxiety and depression, in addition to many sub-cortical/limbic regions), particularly during exposure to negative stimuli. ${ }^{124}$ The biological basis of psychoticism has not been fully identified. Primary research showed that there is the kind of central nervous organization underlying psychoticism, which has been observed in two-flash threshold and electrodermal level. ${ }^{125,126}$ It is reported that psychoticism was linked with several testosterone-related genes, which explained the high level of testosterone in these individuals. ${ }^{127,128}$

\section{Eysenck's model and biological stress responses}

As indicated in Table 1, some studies have not found any association between Eysenck's model and urinary cortisol re- sponse to psychological stress. ${ }^{129,130}$ Nevertheless, an earlier study has shown that neuroticism and extraversion are strong predictors stress-induced neuroendocrine reactions. ${ }^{131}$ The next investigation using Eysenck's model showed that in response to psychological stress, neuroticism positively related to the cortisol secretion ${ }^{89}$ and diastolic blood pressure responses. ${ }^{132}$ Contrary, it is was reported that there was no association between neuroticism of Eysenck's model and the daytime cortisol secretion. ${ }^{133}$ High levels of neuroticism was associated with the blunted cortisol reactivity, and poorer A/Panama antibody response to acute laboratory mental stress. ${ }^{134}$ Whereas in response to the combined dexamethasone-CRH test, lowneuroticism individuals showed a greater cortisol response than high-neuroticism individuals. ${ }^{135}$ Research also reported extraversion negatively associated with the cortisol stress responses. ${ }^{94,99}$ Instead, in response to change in work-related circadian behavior pattern, individuals with high extraversion secreted more cortisol during the day shift, while high introverts produced more cortisol during the night shift. ${ }^{136}$ Despite this, it has been observed that higher introversion of Eysenck's model was associated with a lower cortisol awakening response, and in interaction with gender, higher levels of introversion among males were also associated with the increased cortisol levels at the time of wakeup (Table 1 ). ${ }^{4}$

\section{Biological stress reactivity based on the five-factor approach of personality}

The "big five or five-factor" model (FFM) is known as a broadly accepted construct that describes the diversity of personality in five dimensions: Neuroticism, Extraversion, Openness, Agreeableness, and Conscientiousness. Numerous researchers have stated that the structure of the big five model is a genetically based human personality universal, such that goes beyond language and other cultural differences. ${ }^{137-140}$ Although, some studies suggested extraversion and agreeableness may be more dependent to cultural context, ${ }^{141}$ but lately, based on the FFM, researchers presented the evolutionary approach about personality structure that has stated personality diversity may not be constant among human communities..$^{142,143}$

The FFM provide a psychobiological typology of resistant to stress or stress reactivity. ${ }^{144}$ Previous studies suggested that five big dimensions not only have a moderate heritability, but also because important physiological correlations with biological systems such as cardiovascular and endocrine responses to stress, indicating causal link of psychometrics with biology. ${ }^{145}$ In previous psychophysiological research, the relationship between FFM and stress-sensitive biological systems has been investigated, as shown in Table 2 . Although it must be acknowledged that some studies reported no association between neuroticism of the FFM and cortisol levels, ${ }^{100,146}$ but, in 
Table 1. Summary of findings related to Eysenck's model and biological responses to stress

\begin{tabular}{|c|c|c|c|c|}
\hline Studies & Biological measures & Personality assessment & Type of stress position & Results \\
\hline Arnetz et al. ${ }^{131}$ & $\begin{array}{l}\text { Diastolic and systolic } \\
\text { blood pressure reactions, } \\
\text { heart rate, urinary and } \\
\text { serum cortisol, urinary } \\
\text { adrenaline and } \\
\text { noradrenaline, growth } \\
\text { hormone, prolactin, } \\
\text { progesterone, glucose, } \\
\text { triglycerides }\end{array}$ & $\begin{array}{l}\text { Two dimensions of } \\
\text { eysenck's short } \\
\text { questionnaire: } \\
\text { extrovertness and } \\
\text { neuroticism }\end{array}$ & $\begin{array}{l}\text { Psychological stress } \\
\text { (The colour-word conflict } \\
\text { test and Mental arithmetic } \\
\text { problems) }\end{array}$ & $\begin{array}{l}\text { - Diastolic blood pressure } \\
\text { reactions to Psychological stress } \\
\text { predicted by extrovertness } \\
\text { - } 25 \text { percent of adrenaline response } \\
\text { explained by extrovertness } \\
\text { - High scores in neuroticism } \\
\text { were associated with the lowest } \\
\text { progesterone response to stress. } \\
\text { - } 36 \text { percent of A-prolactin response } \\
\text { explained by neuroticism. }\end{array}$ \\
\hline $\begin{array}{l}\text { Kirschbaum } \\
\text { et al. }{ }^{129}\end{array}$ & Salivary cortisol & $\begin{array}{l}\text { The german version of } \\
\text { the eysenck personality } \\
\text { questionnaire-revised } \\
\text { (EPQ-R) }\end{array}$ & $\begin{array}{l}\text { Psychological stress } \\
\text { (public speaking and } \\
\text { mental arithmetic) }\end{array}$ & $\begin{array}{l}\text { No significant correlation was } \\
\text { observed between Salivary } \\
\text { cortisol and any of the EPQ } \\
\text { measures }\end{array}$ \\
\hline $\begin{array}{l}\text { Kirschbaum } \\
\text { et al. }^{94}\end{array}$ & Salivary cortisol & $\begin{array}{l}\text { Eysenck personality } \\
\text { inventory (EPI; German } \\
\text { version ): extraversion } \\
\text { (EPI-E) and neuroticism } \\
(\text { EPI-N) }\end{array}$ & $\begin{array}{l}\text { Psychological stress } \\
\text { (public speaking and } \\
\text { mental arithmetic in front } \\
\text { of an audience) }\end{array}$ & $\begin{array}{l}\text { - Extraversion negatively } \\
\text { associated with the salivary } \\
\text { cortisol responses to } \\
\text { psychological stress }\end{array}$ \\
\hline Roger et al. ${ }^{89}$ & $\begin{array}{l}\text { Urinary free cortisol test } \\
\text { (UFC) }\end{array}$ & $\begin{array}{l}\text { Eysenck personality } \\
\text { inventory (EPI); } \\
\text { extraversion (EPI-E) and } \\
\text { neuroticism (EPI-N) }\end{array}$ & $\begin{array}{l}\text { Psychological stress } \\
\text { (written examination) }\end{array}$ & $\begin{array}{l}\text { Neuroticism positively was related } \\
\text { to the cortisol secretion }\end{array}$ \\
\hline Senior et al. ${ }^{136}$ & Salivary cortisol & $\begin{array}{l}\text { Extraversion-introversion } \\
\text { scale of the eysenck } \\
\text { personality inventory }\end{array}$ & $\begin{array}{l}\text { Physical stressor } \\
\text { (change in work-related } \\
\text { circadian behavior } \\
\text { pattern) }\end{array}$ & $\begin{array}{l}\text { - Individuals with high } \\
\text { extraversion secreted more } \\
\text { cortisol during the day shift, - } \\
\text { high introverts produced more } \\
\text { cortisol during the night shift }\end{array}$ \\
\hline $\begin{array}{l}\text { Schommer } \\
\text { et al. }^{130}\end{array}$ & Salivary cortisol & $\begin{array}{l}\text { The eysenck personality } \\
\text { questionnaire-revised } \\
\text { (EPQ-R) }\end{array}$ & $\begin{array}{l}\text { Psychosocial stress } \\
\text { (a free speech and a } \\
\text { mental arithmetic task) }\end{array}$ & $\begin{array}{l}\text { No significant correlation was } \\
\text { observed between basal /or } \\
\text { stimulated concentrations of } \\
\text { cortisol and stressful exposure. }\end{array}$ \\
\hline $\begin{array}{l}\text { McCleery } \\
\text { et al. }^{135}\end{array}$ & Plasma cortisol & $\begin{array}{l}\text { Neuroticism dimension of } \\
\text { the eysenck personality } \\
\text { questionnaire (EPQ) }\end{array}$ & $\begin{array}{l}\text { The Combined } \\
\text { dexamethasone-CRH test }\end{array}$ & $\begin{array}{l}\text { Individuals with low-neuroticism } \\
\text { showed a greater cortisol } \\
\text { response than high-neuroticism } \\
\text { individuals }\end{array}$ \\
\hline $\begin{array}{l}\text { Kennedy } \\
\text { et al. }{ }^{132}\end{array}$ & $\begin{array}{l}\text { Cardiovascular measures: } \\
\text { systolic blood pressure } \\
(\mathrm{SBP}) \text {, diastolic blood } \\
\text { pressure (DBP), and } \\
\text { heart rate (HR) activity }\end{array}$ & $\begin{array}{l}\text { Neuroticism dimension of } \\
\text { the eysenck personality } \\
\text { questionnaire (EPQ-R) }\end{array}$ & $\begin{array}{l}\text { Psychological stress } \\
\text { (a mental arithmetic task) }\end{array}$ & $\begin{array}{l}\text { Neuroticism was related to } \\
\text { diastolic blood pressure } \\
\text { responses }\end{array}$ \\
\hline Phillips et al. ${ }^{134}$ & Salivary cortisol & $\begin{array}{l}\text { Neuroticism dimension of } \\
\text { the Eysenck Personality } \\
\text { Questionnaire (EPQ) }\end{array}$ & $\begin{array}{l}\text { Psychological stress } \\
\text { (a mental arithmetic task) }\end{array}$ & $\begin{array}{l}\text { A high level of neuroticism was } \\
\text { associated with the blunted } \\
\text { cortisol reactivity, and poorer A/ } \\
\text { Panama antibody response. }\end{array}$ \\
\hline Ferguson $^{133}$ & The daily salivary cortisol & $\begin{array}{l}\text { Neuroticism dimension of } \\
\text { the Eysenck Personality } \\
\text { Questionnaire (EPQ) }\end{array}$ & Health anxiety (HA) & $\begin{array}{l}\text { There was no association between } \\
\text { neuroticism of and the daytime } \\
\text { cortisol secretion }\end{array}$ \\
\hline
\end{tabular}


Table 1. Summary of findings related to Eysenck's model and biological responses to stress (continued)

\begin{tabular}{|c|c|c|c|c|}
\hline Studies & Biological measures & Personality assessment & Type of stress position & Results \\
\hline Taylor et al. ${ }^{99}$ & Salivary cortisol & $\begin{array}{l}\text { the Extraversion subscale } \\
\text { of the Eysenck } \\
\text { Personality Inventory }\end{array}$ & $\begin{array}{l}\text { Psychological stress } \\
\text { (a speech to audiences and } \\
\text { mental arithmetic tasks) }\end{array}$ & $\begin{array}{l}\text { Extraversion negatively was } \\
\text { associated with the Salivary } \\
\text { cortisol responses to stress }\end{array}$ \\
\hline Hauner et al. ${ }^{4}$ & $\begin{array}{l}\text { Diurnal salivary cortisol } \\
\text { patterns }\end{array}$ & $\begin{array}{l}\text { Four measures of } \\
\text { neuroticism: (EPQ-R), } \\
\text { international } \\
\text { personality item pool } \\
\text { NEO-PI (IPIP) and } \\
\text { big five mini-markers). } \\
\text { Introversion } \\
\text { (low extraversion of big } \\
\text { five mini-markers) }\end{array}$ & Life stress risk factors & $\begin{array}{l}\text { - Higher introversion was } \\
\text { associated with a lower cortisol } \\
\text { awakening response } \\
\text { - In interaction with gender, } \\
\text { higher levels of introversion } \\
\text { among males were associated } \\
\text { with the increased cortisol levels } \\
\text { at the time of wakeup } \\
\text { - A flatter cortisol rhythm was } \\
\text { observed across the waking day } \\
\text { among male participants with } \\
\text { higher Neuroticism }\end{array}$ \\
\hline
\end{tabular}

particular, high neuroticism was associated with more levels of cortisol $^{41,147-149}$ and Salivary alpha amylase ${ }^{39}$ under psychological stress, the diurnal cortisol secretion, ${ }^{150}$ and the increased cortisol levels in response to Dex/CRH test, ${ }^{151}$ which reflecting a more activation of the HPA axis in the neurotic individuals. Also in highly neurotic individuals, blood pressure reactivity to laboratory stressors, ${ }^{152}$ and the lower levels of diastolic blood pressure response, ${ }^{153}$ and higher pre-ejection period (PEP) reactivity ${ }^{154}$ was reported. Neuroticism was also associated with low level of salivary IgA under psychological stress. ${ }^{29}$ However, there were evidences that neuroticism of FFM has been associated with lower cortisol and cardiovascular reactions, ${ }^{3,155}$ as well as in another study, it was not associated with blood pressure, heart rate, urinary cortisol. ${ }^{156}$ Some researchers have argued that the nature of stress-related task plays an important role in stress response. For example, higher neurotic during the cognitive task showed lower DBP and TPRI responses, whereas during the emotional task, lower neuroticism was related to high levels of TPRI reactivity. ${ }^{153}$

On other dimensions of the FFM, extraversion, in interaction with various types of stressors (health, family, social, work) can negatively predict physiological stress response. ${ }^{157}$ Higher extraversion may be associated with a low level of sAA, ${ }^{40}$ lower levels of basal/or increased salivary testosterone, ${ }^{5}$ lower cortisol reactivity, ${ }^{154}$ and lower cardiovascular reactivity ${ }^{153}$ to psychological stress. Furthermore, low levels of extraversion were associated with higher blood pressure, epinephrine, norepinephrine, and natural killer cell cytotoxicity (NK cells). ${ }^{156}$ There is also evidence that Lower extraversion predicts greater cortisol reactivity, ${ }^{146,19}$ and tended to show a low level of cortisol awakening response. ${ }^{100}$ Other research was non-significant, but its findings showed that extraversion of FMM tends to have a lower cortisol response..$^{151}$

Although in a study, agreeableness of FFM in interaction with various types of stressors (health, family, social, work) negatively predicted physiological stress response, ${ }^{157}$ but also, there are some dissimilar findings. For example, individuals with low levels on agreeableness tended to have higher levels of diastolic blood pressure, systolic blood pressure and urinary epinephrine, ${ }^{156}$ and on the other hand, these people also have shown lower levels of cortisol and cardiac reactions to stress. ${ }^{3}$ In addition, another studies displayed that Agreeableness positively related to the levels of cortisol, ${ }^{199,158,159}$ and sAA ${ }^{39}$ under psychological stress. However, some researchers reported a negative correlation between Agreeableness and $\mathrm{sAA}^{40}$ as well as it was related to lower cortisol levels at awakening. ${ }^{160}$ In addition, a negative non-significant and remarkable relationship between Agreeableness and the decreased salivary testosterone response to stress have been reported. ${ }^{5}$

Researchers have found that because having positive affection, individuals with high levels of conscientiousness showed reduction in diurnal cortisol concentration $s^{150,161}$ and lower cortisol reactivity to psychological stress. ${ }^{149}$ In addition, it has been reported that conscientiousness was related to low level of basal/or lower cortisol reactivity, ${ }^{158,162}$ and lower hair cortisol concentration. ${ }^{163}$ There is also a research that reported no correlation between conscientiousness and the cortisol awakening response (CAR), or the diurnal cortisol levels. ${ }^{164}$

Openness to experience is one another of the domains of the FFM. So far, previous psychobiological studies showed a positive association between openness with basal/salivary testosterone, ${ }^{5}$ and $\operatorname{IgA}^{29}$ under psychological stress, while it was negatively correlated with salivary cortisol. ${ }^{41}$ There were also inconsistency findings. for example, the increased corti- 
Table 2. The five-factor model of personality and biological responses to stress

\begin{tabular}{|c|c|c|c|c|}
\hline Studies & Biological measures & Personality assessment & Type of stress position & Results \\
\hline Vickers et al. ${ }^{158}$ & Blood cortisol levels & $\begin{array}{l}\text { The } 181 \text {-item NEO } \\
\text { personality inventory } \\
\text { (NEO-PI) }\end{array}$ & $\begin{array}{l}\text { Physical stress } \\
\text { (Military basic training) }\end{array}$ & $\begin{array}{l}\text { - Agreeableness was associated to } \\
\text { higher cortisol } \\
\text { - Conscientiousness was related } \\
\text { to lower cortisol }\end{array}$ \\
\hline Miller et al. ${ }^{156}$ & $\begin{array}{l}\text { Blood pressure and heart } \\
\text { rate, neuroendocrine } \\
\text { parameters(urinary } \\
\text { Epinephrine, } \\
\text { norepinephrine, and } \\
\text { cortisol) and immune } \\
\text { parameters } \\
\text { (T lymphocytes, helper } \\
\text { T lymphocytes, } \\
\text { cytotoxic/suppressor T } \\
\text { lymphocytes, B cells, and } \\
\text { natural killer cells) }\end{array}$ & $\begin{array}{l}\text { Big five personality } \\
\text { factors of goldberg's } \\
(1992)\end{array}$ & $\begin{array}{l}\text { Physical laboratory stress } \\
\text { (viral exposure) }\end{array}$ & $\begin{array}{l}\text { - Low agreeableness has showed } \\
\text { higher levels of systolic blood } \\
\text { pressure, diastolic blood } \\
\text { pressure, and urinary } \\
\text { epinephrine } \\
\text { - Low extroversion was related } \\
\text { to higher levels of epinephrine, } \\
\text { blood pressure, norepinephrine, } \\
\text { and natural killer cell } \\
\text { cytotoxicity } \\
\text { - Neuroticism was not associated } \\
\text { with physiological outcomes }\end{array}$ \\
\hline Schwebel et al. ${ }^{152}$ & $\begin{array}{l}\text { Cardiovascular } \\
\text { reactivity (blood } \\
\text { pressure and heart rate) }\end{array}$ & $\begin{array}{l}\text { The NEO PI-R } \\
\text { neuroticism scale }\end{array}$ & $\begin{array}{l}\text { Psychological and } \\
\text { physical stressor } \\
\text { (laboratory reactivity tasks) }\end{array}$ & $\begin{array}{l}\text { Blood pressure reactivity to } \\
\text { laboratory stressors reported in } \\
\text { highly neurotic individuals }\end{array}$ \\
\hline $\begin{array}{l}\text { Zobel } \\
\text { et al. }^{151}\end{array}$ & Blood cortisol levels & $\begin{array}{l}\text { NEO-five-factors } \\
\text { Inventory (NEO-FFI) }\end{array}$ & Combined dex/CRH tests & $\begin{array}{l}\text { Participants with high } \\
\text { neuroticism revealed high levels } \\
\text { of cortisol }\end{array}$ \\
\hline Oswald et al. ${ }^{155}$ & $\begin{array}{l}\text { Plasma concentrations } \\
\text { of cortisol }\end{array}$ & $\begin{array}{l}\text { The revised NEO } \\
\text { personality inventory } \\
\text { (NEO PI-R) }\end{array}$ & $\begin{array}{l}\text { Psychological stress (mental } \\
\text { arithmetic challenge) }\end{array}$ & $\begin{array}{l}\text { - In total sample, low levels of } \\
\text { openness were associated with } \\
\text { lower cortisol responses } \\
\text { - In the interaction of gender, the } \\
\text { low cortisol responses were } \\
\text { associated with higher } \\
\text { neuroticism in women and } \\
\text { with lower extraversion in men }\end{array}$ \\
\hline Tops et al. ${ }^{159}$ & Salivary cortisol responses & $\begin{array}{l}\text { Five factor personality } \\
\text { inventory (FFPI) }\end{array}$ & $\begin{array}{l}\text { Physical laboratory stress (the } \\
\text { Eriksen Flanker Task while } \\
\text { by EEG was } \\
\text { recorded) }\end{array}$ & $\begin{array}{l}\text { Agreeableness positively related } \\
\text { to the levels of Salivary cortisol }\end{array}$ \\
\hline Hauner et al. ${ }^{4}$ & $\begin{array}{l}\text { Diurnal salivary cortisol } \\
\text { patterns }\end{array}$ & $\begin{array}{l}\text { Four measures of } \\
\text { neuroticism: (EPQ-R), } \\
\text { international } \\
\text { personality item pool } \\
\text { NEO-PI (IPIP) and } \\
\text { big five mini-markers). } \\
\text { Introversion (low } \\
\text { extraversion of big five } \\
\text { mini-markers) }\end{array}$ & Life stress risk factors & $\begin{array}{l}\text { High neuroticism among males } \\
\text { were associated with a flatter } \\
\text { diurnal cortisol response }\end{array}$ \\
\hline $\begin{array}{l}\text { Jonassaint } \\
\text { et al. }^{153}\end{array}$ & $\begin{array}{l}\text { Cardiovascular } \\
\text { reactivity: heart rate, } \\
\text { blood pressure, cardiac } \\
\text { output index, total } \\
\text { peripheral resistance } \\
\text { index (TPRI) }\end{array}$ & $\begin{array}{l}\text { Neuroticism and } \\
\text { extraversion of the NEO } \\
\text { PI-R }\end{array}$ & $\begin{array}{l}\text { Psychological stress: } \\
\text { a cognitive task as mental } \\
\text { arithmetic (MA) and an } \\
\text { emotional task as The anger } \\
\text { recall (AR) }\end{array}$ & $\begin{array}{l}\text { - High extraversion was related to } \\
\text { lower cardiovascular reactivity } \\
\text { on both tasks } \\
\text { - High neuroticism was } \\
\text { associated with low levels of } \\
\text { DBP and TPRI reactivity } \\
\text { during MA, Whereas during } \\
\text { AR, lower N associated with } \\
\text { high TPRI reactivity }\end{array}$ \\
\hline
\end{tabular}


Table 2. The five-factor model of personality and biological responses to stress (continued)

\begin{tabular}{|c|c|c|c|c|}
\hline Studies & Biological measures & Personality assessment & Type of stress position & Results \\
\hline Nater et al. ${ }^{150}$ & $\begin{array}{l}\text { Salivary diurnal cortisol } \\
\text { levels }\end{array}$ & $\begin{array}{l}\text { Neuroticism and } \\
\text { conscientiousness of the } \\
\text { NEO-FFI }\end{array}$ & - & $\begin{array}{l}\text { - N was positively associated with } \\
\text { cortisol levels during all periods } \\
\text { of measurement } \\
\text { - Because having positive } \\
\text { affection, individuals with high } \\
\text { levels of conscientiousness } \\
\text { showed reductions in diurnal } \\
\text { cortisol concentrations }\end{array}$ \\
\hline Inukai et al..$^{40}$ & $\begin{array}{l}\text { Baseline salivary } \\
\text { alpha-amylase (sAA) }\end{array}$ & $\begin{array}{l}\text { The } 70 \text {-item Big Five } \\
\text { Inventory (BFI) }\end{array}$ & - & $\begin{array}{l}\text { - Between neuroticism and sAA } \\
\text { were observed a positive } \\
\text { correlation } \\
\text { - Agreeableness was positively } \\
\text { correlated with sAA. } \\
\text { - Extraversion, agreeableness, } \\
\text { openness were negatively } \\
\text { related to sAA after controlling } \\
\text { for age }\end{array}$ \\
\hline $\begin{array}{l}\text { van Santen } \\
\text { et al. }{ }^{100}\end{array}$ & $\begin{array}{l}\text { Salivary cortisol } \\
\text { awakening responses }\end{array}$ & $\begin{array}{l}\text { The } 60 \text {-item NEO-FFI } \\
\text { personality Inventory }\end{array}$ & - & $\begin{array}{l}\text { - Individuals with higher levels } \\
\text { of extraversion have tended } \\
\text { to a lower cortisol awakening } \\
\text { response } \\
\text { - No significant associations were } \\
\text { found for neuroticism, } \\
\text { conscientiousness, openness, } \\
\text { agreeableness, }\end{array}$ \\
\hline $\begin{array}{l}\text { Agrigoroaei } \\
\text { et al. }{ }^{149}\end{array}$ & Salivary cortisol levels & The 240-item NEO-PI-R & $\begin{array}{l}\text { Psychological stress : } \\
\text { challenging driving } \\
\text { scenario with simulator }\end{array}$ & $\begin{array}{l}\text { - Individuals with higher levels } \\
\text { of conscientiousness showed } \\
\text { lower cortisol reactivity } \\
\text { - Neuroticism, agreeableness and } \\
\text { extraversion were } \\
\text { positively related to greater } \\
\text { cortisol reactivity }\end{array}$ \\
\hline Gartland $^{164}$ & $\begin{array}{l}\text { The diurnal salivary } \\
\text { cortisol levels }\end{array}$ & $\begin{array}{l}\text { Chernyshenko } \\
\text { conscientiousness scales }\end{array}$ & Daily perceived stress & $\begin{array}{l}\text { No correlation was found } \\
\text { between conscientiousness and } \\
\text { the diurnal cortisol levels }\end{array}$ \\
\hline Bibbey et al. ${ }^{3}$ & $\begin{array}{l}\text { Salivary cortisol and } \\
\text { cardiovascular activity: } \\
\text { Heart rate, blood } \\
\text { pressure }\end{array}$ & $\begin{array}{l}\text { The Big Five Inventory } \\
\text { (BFI) }\end{array}$ & $\begin{array}{l}\text { Three psychological stress } \\
\text { tasks: stroop, mirror } \\
\text { tracing, and speech }\end{array}$ & $\begin{array}{l}\text { - Higher neuroticism was related } \\
\text { to lower cortisol and } \\
\text { cardiovascular stress reactions } \\
\text { - Low agreeableness and low } \\
\text { openness had shown lower } \\
\text { cortisol and cardiac reactions to } \\
\text { stress }\end{array}$ \\
\hline Chu et al. ${ }^{157}$ & $\begin{array}{l}\text { Physiological stress } \\
\text { response measured by } \\
\text { Work Stress Scale }\end{array}$ & $\begin{array}{l}\text { NEO-personality } \\
\text { inventory }\end{array}$ & $\begin{array}{l}\text { Types of stressors (health, } \\
\text { family, social, work) of } \\
\text { Work Stress Scale }\end{array}$ & $\begin{array}{l}\text { - Interaction of stressors (health, } \\
\text { family, social, work) and } \\
\text { agreeableness negatively predict } \\
\text { physiological stress response } \\
\text { - Interaction of stressors (health, } \\
\text { family, social, work) and } \\
\text { Extraversion negatively predict } \\
\text { physiological stress response }\end{array}$ \\
\hline Afrisham et al..$^{39}$ & $\begin{array}{l}\text { Salivary alpha amylase } \\
\text { reactivity }\end{array}$ & $\begin{array}{l}\text { The } 60 \text {-item NEO-FFI } \\
\text { personality Inventory }\end{array}$ & $\begin{array}{l}\text { Psychological stress: exam } \\
\text { stress }\end{array}$ & $\begin{array}{l}\text { Neuroticism and agreeableness } \\
\text { were positively correlated with SAA }\end{array}$ \\
\hline
\end{tabular}


Table 2. The five-factor model of personality and biological responses to stress (continued)

\begin{tabular}{|c|c|c|c|c|}
\hline Studies & Biological measures & Personality assessment & Type of stress position & Results \\
\hline Laceulle et al. ${ }^{162}$ & $\begin{array}{l}\text { Basal salivary cortisol } \\
\text { and cortisol awakening } \\
\text { responses }\end{array}$ & $\begin{array}{l}\text { The revised NEO } \\
\text { personality inventory } \\
\text { (NEO PI-R) }\end{array}$ & $\begin{array}{l}\text { Physical laboratory and } \\
\text { psychosocial stress: } \\
\text { orthostatic stress (from } \\
\text { supine to standing), a spatial } \\
\text { orienting task, a gambling } \\
\text { task, a startle reflex task, } \\
\text { and a social stress test }\end{array}$ & $\begin{array}{l}\text { Neuroticism, extraversion and } \\
\text { conscientiousness were related } \\
\text { to low level of basal cortisol }\end{array}$ \\
\hline Bogg et al. ${ }^{161}$ & $\begin{array}{l}\text { The diurnal salivary } \\
\text { cortisol levels }\end{array}$ & $\begin{array}{l}\text { Neuroticism and } \\
\text { conscientiousness of } \\
\text { NEO-personality } \\
\text { inventory }\end{array}$ & Daily stressors & $\begin{array}{l}\text { High conscientiousness is } \\
\text { associated with reductions in } \\
\text { diurnal cortisol concentrations }\end{array}$ \\
\hline $\begin{array}{l}\text { Parent-Lamarche } \\
\text { et al. }{ }^{160}\end{array}$ & $\begin{array}{l}\text { The diurnal Salivary } \\
\text { cortisol levels }\end{array}$ & $\begin{array}{l}\text { The } 20 \text {-item Mini } \\
\text { International } \\
\text { Personality Item Pool } \\
\text { (Mini-IPIP) }\end{array}$ & $\begin{array}{l}\text { Psychosocial stress: Stressful } \\
\text { life events, Marital stress, } \\
\text { Parental stress }\end{array}$ & $\begin{array}{l}\text { Agreeableness was associated } \\
\text { with lower cortisol levels at } \\
\text { awakening }\end{array}$ \\
\hline Afrisham et al. ${ }^{29}$ & $\begin{array}{l}\text { Levels of salivary } \\
\text { immunoglobulin A }\end{array}$ & $\begin{array}{l}\text { The } 60 \text {-item NEO-FFI } \\
\text { personality Inventory }\end{array}$ & $\begin{array}{l}\text { Psychological stress: exam } \\
\text { stress }\end{array}$ & $\begin{array}{l}\text { - A negative correlation was } \\
\text { found between neuroticism and } \\
\text { salivary IgA } \\
\text { - Openness was positively } \\
\text { correlated with salivary IgA }\end{array}$ \\
\hline Afrisham et al. ${ }^{5}$ & $\begin{array}{l}\text { Salivary Testosterone } \\
\text { Levels }\end{array}$ & $\begin{array}{l}\text { The } 60 \text {-item NEO-FFI } \\
\text { personality Inventory }\end{array}$ & $\begin{array}{l}\text { Psychological stress: exam } \\
\text { stress }\end{array}$ & $\begin{array}{l}\text { - Openness was positively } \\
\text { correlated with salivary } \\
\text { testosterone } \\
\text { - A negative correlation was } \\
\text { found between extroversion } \\
\text { and salivary testosterone }\end{array}$ \\
\hline Evans et al. ${ }^{154}$ & $\begin{array}{l}\text { Salivary cortisol and } \\
\text { Heart rate reactivity, } \\
\text { pre-ejection period } \\
(\mathrm{PEP})\end{array}$ & $\begin{array}{l}\text { Extraversion and } \\
\text { neuroticism of Big Five } \\
\text { personality markers }\end{array}$ & $\begin{array}{l}\text { Psychosocial stress: the } \\
\text { speech delivery and social } \\
\text { evaluation }\end{array}$ & $\begin{array}{l}\text { - Higher levels of extraversion } \\
\text { showed lower cortisol reactivity } \\
\text { - higher level of neuroticism } \\
\text { showed higher PEP reactivity }\end{array}$ \\
\hline $\begin{array}{l}\text { Sadegh-Nejadi } \\
\text { et al. }{ }^{41}\end{array}$ & Salivary cortisol reactivity & $\begin{array}{l}\text { The } 60 \text {-item NEO-FFI } \\
\text { personality Inventory }\end{array}$ & $\begin{array}{l}\text { Psychological stress: exam } \\
\text { stress }\end{array}$ & $\begin{array}{l}\text { - A Positive correlation was } \\
\text { found between neuroticism and } \\
\text { salivary cortisol } \\
\text { - Openness has a negative } \\
\text { correlation with salivary } \\
\text { cortisol response }\end{array}$ \\
\hline Ouanes et al. ${ }^{146}$ & $\begin{array}{l}\text { Salivary Cortisol } \\
\text { Awakening } \\
\text { Response and Cortisol } \\
\text { AUC (Area Under the } \\
\text { Curve) }\end{array}$ & $\begin{array}{l}\text { The 60-item Revised } \\
\text { NEO Five Factor } \\
\text { Inventory (NEO-FFI-R) }\end{array}$ & - & $\begin{array}{l}\text { - High extraversion was negatively } \\
\text { associated with Cortisol AUC. } \\
\text { - High openness was associated } \\
\text { with higher cortisol } \\
\text { - No correlation was found } \\
\text { between neuroticism and } \\
\text { cortisol levels }\end{array}$ \\
\hline Steptoe et al..$^{163}$ & $\begin{array}{l}\text { Hair cortisol } \\
\text { concentration }\end{array}$ & $\begin{array}{l}\text { The Midlife } \\
\text { Development } \\
\text { Inventory (MIDI) } \\
\text { Personality Scales }\end{array}$ & $\begin{array}{l}\text { Socioeconomic position: } \\
\text { Educational attainment and } \\
\text { wealth }\end{array}$ & $\begin{array}{l}\text { Conscientiousness was related to } \\
\text { lower hair cortisol } \\
\text { concentration }\end{array}$ \\
\hline Russell $^{148}$ & Salivary Cortisol response & $\begin{array}{l}\text { The 60-item Revised } \\
\text { NEO Five Factor } \\
\text { Inventory (NEO-FFI-R) }\end{array}$ & $\begin{array}{l}\text { Psychosocial stress: the Trier } \\
\text { Social Stress Test (TSST) }\end{array}$ & $\begin{array}{l}\text { High neuroticism was associated } \\
\text { with more levels of cortisol }\end{array}$ \\
\hline
\end{tabular}


sol, ${ }^{146}$ and or the lower cortisol responses ${ }^{155}$ were associated with low levels of openness.

On the reviewed studies, some researchers believed that cortisol reactivity may be corresponded to certain personality dimensions of FFM in a gender-specific manner. Thus, they evaluated gender effects on relationship between the FFM and HPA axis activation. Their results demonstrated that the low cortisol responses were associated with higher neuroticism in women and with lower extraversion in men. ${ }^{155}$ an another study also reported that high neuroticism among males were associated with a flatter diurnal cortisol response. ${ }^{4}$

\section{Other personality profiles and biological stress response}

In addition to the researches based on the presented four models, a number of psycho-neuroendocorinal studies have used other personality profiles to find out the relationship between personality and biological stress response. For example, the individuals with type-A behavior have shown the high level of basal and/or lower adrenocortical reactivity, ${ }^{96}$ while type-D behavior (or 'distressed' personality) was associated with higher cortisol reactivity to stress. ${ }^{165}$ Also, a research using the dimensions of (TCI) showed that Masterful Subjects (highly self-directedness and mastery individuals) showed low alpha-amylase reactivity, and moderate level of cortisol reactivity, whereas trustful subjects (or highly cooperative and trustful individuals), had low cortisol reactivity. In addition, courageous Subjects (or individuals with higher harm Avoidance, lower Self-directedness, and partially lower Self-transcendence) has shown high sympathetic reactivity, while their cortisol activation was moderate. ${ }^{166}$

\section{Conclusion}

According to the results of this review, it can be concluded that personality typology of individuals influences their biological reactivity to stressful events. Actually, differences in biological reactivity to stress may be caused by a different biological personality. Commonly, the biological stress responses have been investigated by current biomarkers of stress-sensitive biological systems such as HPA axis, the autonomic nervous system, the immune system, sympathetic-adrenal-medulla system, and sex hormones. In addition, of the presented four models, the models of psychosocial characteristics, rumination and emotional inhibition include dimensions of higher-order personality and groups of more specific traits. Whereas, Eysenck's model and specifically big five personality traits are not only reflected more extensive and organized personality structures, but also included most basic and higher-order dimensions of personality. Future research can be continuing based on the framework of the four models.
In general, from a biological perspective, Personality as a set of traits or characteristics can be determined based on biological bases, more precisely neural mechanisms and brain structures. In other words, the human may have a biological personality that influences the way of thinking, behavior and as well how to interact with themselves and environment. Whether the biological personality is derived from heredity (nature) or learning (nurture) and or interaction between them, requires more future research in this field. The anatomical features of the brain can be different, and this is the basis of personality differences, especially in people with mental disorders. For example, studies showed that the brain anatomy of individuals with cluster B personality disorders has features such as abnormalities in the amygdala, superior frontal cortex and enlarged striatal volumes. ${ }^{167}$ Hence, understanding the biological basis of personality can be effective in improving diagnosis as well as decision making about clinical management and therapeutic options.

\section{Acknowledgments}

We would like to acknowledge the Department of Clinical Biochemistry, School of Medicine, Tehran University of Medical Sciences, for their assistances. We also thank Prof. Urs Markus Nater for his guidance in writing this paper.

\section{REFERENCES}

1. Papathanasiou IV, Tsaras K, Neroliatsiou A, Roupa A. Stress: Concepts, theoretical models and nursing interventions. Am J Nurs Sci 2015;4: 45-50.

2. Martin P, Long MV, Poon LW. Age changes and differences in personality traits and states of the old and very old. J Gerontol B Psychol Sci Soc Sci 2002;57:P144-P152.

3. Bibbey A, Carroll D, Roseboom TJ, Phillips AC, de Rooij SR. Personality and physiological reactions to acute psychological stress. Int J Psychophysiol 2013;90:28-36.

4. Hauner KK, Adam EK, Mineka S, Doane LD, DeSantis AS, Zinbarg R, et al. Neuroticism and introversion are associated with salivary cortisol patterns in adolescents. Psychoneuroendocrinology 2008;33:1344-1356.

5. Afrisham R, Sadegh-Nejadi S, SoliemaniFar O, Kooti W, AshtaryLarky D, Alamiri F, et al. Salivary testosterone levels under psychological stress and its relationship with rumination and five personality traits in medical students. Psychiatry Investig 2016;13:637-643.

6. Park S, Song YM, Ko GN, Jhung K, Ha K, Lee YR, et al. The relationship between personality, sense of efficacy, and stress in Korean teachers. Psychiatry Investig 2016;13:566-570.

7. Šíchová K, Koskela E, Mappes T, Lantova P, Boratynski Z. On personality, energy metabolism and mtDNA introgression in bank voles. Anim Behav 2014;92:229-237.

8. Petticrew MP, Lee K. The "father of stress" meets "big tobacco": Hans Selye and the tobacco industry. Am J Public Health 2011;101:411-418.

9. Szabo S, Tache Y, Somogyi A. The legacy of Hans Selye and the origins of stress research: a retrospective 75 years after his landmark brief "letter" to the editor\# of nature. Stress 2012;15:472-478.

10. Koolhaas J, Bartolomucci A, Buwalda B, de Boer SF, Flügge G, Korte SM, et al. Stress revisited: a critical evaluation of the stress concept. Neurosci Biobehav Rev 2011;35:1291-1301.

11. Wheatley MA. Personal Characteristics, Chronic Stress, and Depressive Symptoms in Midlife African-American Women. Cleveland, Ohio: 
Doctor of Philosophy (Electronic Thesis or Dissertation) Case Western Reserve University; 2009.

12. Figueroa-Fankhanel F. Measurement of stress. Psychiatr Clin North Am 2014;37:455-487.

13. Rice VH. Theories of Stress and Its Relationship to Health. In: Rice VH, Editor. Handbook of Stress, Coping, and Health: Implications for Nursing Research, Theory, and Practice. Second Edition. Los Angeles: Sage Publications, 2012, p.22-42.

14. Selye H. Stress and the general adaptation syndrome. Br Med J 1950;1: 1383-1392.

15. Krohne HW. Stress and coping theories. Int Encyclopedia Soc Behav Sci 2002;22:15163-15170.

16. Holmes TH. Life situations, emotions, and disease. Psychosomatics 1978;19:747-754.

17. Bailey R, Clarke M. Stress and Coping in Nursing. In: Bailey R, Clarke M, Editors. Meanings and Models of Stress and Coping. 1st Edition. Boston, MA: Springer, 1989, p.3-34.

18. Lazarus RS, Launier R. Stress-Related Transactions between Person and Environment. In: Lazarus RS, Launier R, Editors. Perspectives in Interactional Psychology. 1st Edition. Boston, MA: Springer, 1978, p.287-327.

19. Cohen F, Lazarus RS. Coping and Adaptation in Health and Illness. In: Mechanic D, Editor. Handbook of Health, Health Care, and the Health Professions. 1st Edition. New York: Free Press,1983, p.608- 635.

20. Folkman S. Stress: Appraisal and Coping. In: Gellman MD, Turner JR, Editors. Encyclopedia of Behavioral Medicine. New York, NY: Springer, 2013, p.1913-1915.

21. Ursin H, Eriksen HR. The cognitive activation theory of stress. Psychoneuroendocrinology 2004;29:567-592.

22. Rossi AM, Meurs JA, Perrewe PL. Stress and Quality of Working Life: Conceptualizing and Assessing Stress. Charlotte, NC: Information Age Publishing Inc.; 2017.

23. Ursin H, Bergan T, Collet J, Endresen IM, Lugg DJ, Maki P, et al. Psychobiological studies of individuals in small, isolated groups in the Antarctic and in space analogues. Environ Behav 1991;23:766-781.

24. Cohen S, Kamarck T, Mermelstein R. A global measure of perceived stress. J Health Soc Behav 1983:385-396.

25. Cooper CL. Stress in the workplace. Br J Hosp Med 1996;55:559-563.

26. Sun J, Dunne MP, Hou XY, Xu AQ. Educational stress scale for adolescents: development, validity, and reliability with Chinese students. J Psychoeduc Assess 2011;29:534-546.

27. Gadzella BM. Student-life stress inventory: Identification of and reactions to stressors. Psychol Rep 1994;74:395-402.

28. Nater UM, Skoluda N, Strahler J. Biomarkers of stress in behavioural medicine. Curr Opin Psychiatry 2013;26:440-445.

29. Afrisham R, Aberomand M, SoliemaniFar O, Kooti W, Ashtary-Larky $\mathrm{D}$, Alamiri F, et al. Levels of salivary immunoglobulin A under psychological stress and its relationship with rumination and five personality traits in medical students. Eur J Psychiatry 2016;30:41-53.

30. Eriksen HR, Ursin H. Subjective health complaints: Is coping more important than control? Work Stress 1999;13:238-252.

31. Spielberger CD. The Measurement of State and Trait Anxiety: Conceptual and Methodological Issues. In: Levi L, Editor. Their Parameters and Measurement. New York: Raven Press, 1976, p.713-725.

32. Piazza JR, Almeida DM, Dmitrieva NO, Klein LC. Frontiers in the use of biomarkers of health in research on stress and aging. J Gerontol B Psychol Sci Soc Sci 2010;65:513-525.

33. Wan, C, Couture-Lalande, MẼ, Narain, TA, Lebel S, Bielajew C. Salivary alpha-amylase reactivity in breast cancer survivors. Int J Environ Res Public Health 2016;13:353.

34. Vineetha R, Pai KM, Vengal M, Gopalakrishna K, Narayanakurup D. Usefulness of salivary alpha amylase as a biomarker of chronic stress and stress related oral mucosal changes-a pilot study. J Clin Exp Dent 2014;6:e132-137.

35. Nater UM, La Marca R, Florin L, Moses A, Langhans W, Koller MM, et al. Stress-induced changes in human salivary alpha-amylase activity-associations with adrenergic activity. Psychoneuroendocrinology 2006;31:49-58.

36. Chen XH, Huang S, Kerr D. Biomarkers in clinical medicine. IARC Sci Publ 2011;163:303-322.

37. Biomarkers Definitions Working Group. Biomarkers and surrogate endpoints: preferred definitions and conceptual framework. Clin Pharmacol Ther 2001;69:89-95.

38. Rohleder N, Nater UM, Wolf JM, Ehlert U, Kirshbaum C. Psychosocial stress-induced activation of salivary alpha-amylase: an indicator of sympathetic activity? Ann N Y Acad Sci 2004;1032:258-263.

39. Afrisham R, Sadegh-Nejadi S, SoliemaniFar O, Abromand M, Kooti W, Najjar Asl S, et al. Evaluating the salivary alpha-amylase level under psychological stress and its relationship with rumination and the fve personality traits. J Mazandaran Univ Med Sc 2015;25:22-33.

40. Inukai K, Shinada M, Tanida S, Takahashi C, Mifune N, Takagishi H, et al. Salivary alpha-amylase levels and big five personality factors in adults. Neuroendocrinol Lett 2010;31:771-774.

41. Sadegh-Nejadi S, Afrisham R, Soliemanifar O, Kooti W, Aberomand $\mathrm{M}$, Najjar-Asl S, et al. Alteration of the level of salivary cortisol under psychological stress and its relationship with rumination and personality traits. J Gorgan Univ Med Sci 2017;19.

42. Segerstrom SC, Miller GE. Psychological stress and the human immune system: a meta-analytic study of 30 years of inquiry. Psychol Bull 2004;130:601-630.

43. Herbert TB, Cohen S. Stress and immunity in humans: a meta-analytic review. Psychosom Med 1993;55:364-379.

44. Tsujita S, Morimoto K. Secretory IgA in saliva can be a useful stress marker. Environ Health Prev Med 1999;4:1-8.

45. Svobodová I, Chaloupková H, Končel R, Bartoš L, Hradecká L, Jebavý L. Cortisol and secretory immunoglobulin a response to stress in German shepherd dogs. PLoS one 2014;9:e90820.

46. Hirokawa K, Miwa M, Taniguchi T, Tsuchiya M, Kawakami N. Moderating effects of salivary testosterone levels on associations between job demand and psychological stress response in Japanese medical workers. Ind Health 2016;54:194-203.

47. Hansen ÅM, Larsen AD, Rugulies R, Garde AH, Knudsen LE. A review of the effect of the psychosocial working environment on physiological changes in blood and urine. Basic Clin Pharmacol Toxicol 2009;105:73-83.

48. Knol, BW. Stress and the endocrine hypothalamus-pituitary-testis system: a review. Vet Q 1991;13:104-114.

49. Maestripieri D, Baran MN, Sapienza P, Zingales L. Between-and within-sex variation in hormonal responses to psychological stress in a large sample of college students. Stress 2010;13:413-424.

50. Wegner M, Koedijker JM, Budde H. The effect of acute exercise and psychosocial stress on fine motor skills and testosterone concentration in the saliva of high school students. PLoS one 2014;9:e92953.

51. Schulz P, Walker JP, Peyrin L, Soulier V, Curtin F, Steimer T. Lower sex hormones in men during anticipatory stress. Neuroreport 1996;7: 3101-3104.

52. Mozafar A, Keshavarz M, Zareian P, Johary H, Jahromy HK, Hoseini S. Te effect of immobilization stress on the HPG axis (hypothalamicpituitary-gonad) hormones and the number of spermatogonia. J Fasa Univ Med Sci 2013;3:280-284.

53. Choi J, Chung M, Lee Y. Modulation of pain sensation by stress-related testosterone and cortisol. Anaesthesia 2012;67:1146-1151.

54. Rivier C, Rivest S. Effect of stress on the activity of the hypothalamicpituitary-gonadal axis: peripheral and central mechanisms. Biol Reprod 1991;45:523-532.

55. Pasquali R. The hypothalamic-pituitary-adrenal axis and sex hormones in chronic stress and obesity: pathophysiological and clinical aspects. Ann N Y Acad Sci 2012;1264:20-35.

56. Tanriverdi F, Silveira L, MacColl G, Bouloux PM. The hypothalamicpituitary-gonadal axis: immune function and autoimmunity. J Endo- 
crinol 2003;176:293-304.

57. Sadeghi A, Niyafar GH, Pour AH, Zamani A, Gholami F. Relationship between personality types and job stress among teachers at first period (guidance schools) and second period of high school (secondary schools). Creat Educ 2016;7:544.

58. Costa PT, McCrae RR. Trait Theories of Personality. In: Barone DF, Hersen M, Van Hasselt VB, Editors. Advanced Personality. 1st Edition. Boston, MA: Springer, 1998, p.103-121.

59. McCrae RR. Personality theories for the 21st century. Teach Psychol 2011;38:209-214.

60. Costa PT, McCrae RR. Normal personality assessment in clinical practice: the NEO Personality Inventory. Psychol Assess 1992;4:5-13.

61. Barrett PT, Petrides KV, Eysenck SB, Eysenck HJ. The Eysenck Personality Questionnaire: an examination of the factorial similarity of $\mathrm{P}$, E, N, and L across 34 countries. Pers Individ Dif 1998;25:805-819.

62. Eysenck HJ. Biological basis of personality. Nature 1963;199:10311034.

63. Salgado JF, Táuriz G. The Five-Factor Model, forced-choice personality inventories and performance: a comprehensive meta-analysis of academic and occupational validity studies. Eur J Work Organ Psychol 2014;23:3-30.

64. Lee K, Ogunfowora B, Ashton MC. Personality traits beyond the Big Five: Are they within the HEXACO space? J Pers 2005;73:1437-1463.

65. Vollrath M. Personality and stress. Scand J Psychol 2001;42:335-347.

66. Dumitru VM, Cozman D. The relationship between stress and personality factors. Hum Vet Med 2012;4:34-39.

67. Kaur R, Chodagiri VK, Reddi NK. A psychological study of stress, personality and coping in police personnel. Indian J Psychol Med 2013;35:141-147.

68. Huh MJ, Shim G, Byun MS, Kim SN, Kim E, Jang JH, et al. The impact of personality traits on ratings of obsessive-compulsive symptoms. Psychiatry Investig 2013;10:259-265.

69. Na HR, Kang EH, Yu BH, Woo JM, Kim YR, Lee SH, et al. Relationship between personality and insomnia in panic disorder patients. Psychiatry Investig 2011;8:102-106.

70. Cussen VA, Mench JA. The relationship between personality dimensions and resiliency to environmental stress in orange-winged amazon parrots (Amazona amazonica), as indicated by the development of abnormal behaviors. PLoS One 2015;10:e0126170.

71. Cockrem JF. Stress, corticosterone responses and avian personalities. J Ornithol 2007;148:169-178.

72. Kobasa SC. Stressful life events, personality, and health: an inquiry into hardiness. J Pers Soc Psychol 1979;37:1-11.

73. Bandura A. Perceived self-efficacy in cognitive development and functioning. Educ Psychol 1993;28:117-148.

74. Scheier MF, Carver CS. Optimism, coping, and health: assessment and implications of generalized outcome expectancies. Health Psychol 1985;4:219-247.

75. Rosenbaum M. Self-control under stress: the role of learned resourcefulness. Adv Behav Res Ther 1989;11:249-258.

76. Snyder CR, Harris C, Anderson JR, Holleran SA, Irving LM, Sigmon ST, et al. The will and the ways: development and validation of an individual-differences measure of hope. J Pers Soc Psychol 1991;60:570-585.

77. Antonovsky, A. The structure and properties of the sense of coherence scale. Soc Sci Med 1993;36:725-733.

78. Brebner J. Personality and stress coping. Pers Individ Dif 2001;31:317327.

79. Evans W. Personality and stress. Pers Individ Dif 1986;7:251-253.

80. Chai MS, Low CS. Personality, coping and stress among university students. Am J Appl Psychol 2015;4:33-38.

81. Afshar H, Roohafza HR, Keshteli AH, Mazaheri M, Feizi A, Adibi P. The association of personality traits and coping styles according to stress level. J Res Med Sci 2015;20:353.

82. Čabarkapa M, Korica V, Rođenkov S. Personal traits and a sense of job-related stress in a military aviation crew. Vojnosanitetski Pregled
2011;68:143-149.

83. Vollrath M, Torgersen S. Personality types and coping. Pers Individ Dif 2000;29:367-378.

84. Eriega EG, Chidozie IG, Tunde OT, Adebunmi WA. Personality and demographic factors as correlates of post-traumatic stress disorder (ptsd) among flood victims. Br J Educ 2014;2:82-88.

85. Bedin JE, Mattjie ML, Ferreira VRT, Baseggio DB. The relationship between personality traits and stress levels in children. Psychology 2015;6:672-680.

86. Richter J, Lauritz LE, du Preez E, Cassimjee N, Ghazinour M. Relationships between personality and coping with stress: an investigation in Swedish police trainees. Psychology 2013;4:88-95.

87. Flaa A, Ekeberg Ø, Kjeldsen SE, Rostrup M. Personality may influence reactivity to stress. Biopsychosoc Med 2007;1:5.

88. Desa A, Yusooff F, Ibrahim N, Kadir NB, Ab Rahman RM. A study of the relationship and influence of personality on job stress among academic administrators at a university. Procedia Soc Behav Sci 2014;114: 355-359.

89. Roger D, Najarian B. The relationship between emotional rumination and cortisol secretion under stress. Pers Individ Dif 1998;24:531-538.

90. Pruessner JC, Gaab J, Hellhammer DH, Lintz D, Schommer N, Kirschbaum C. Increasing correlations between personality traits and cortisol stress responses obtained by data aggregation. Psychoneuroendocrinology 1997;22:615-625.

91. Seeman TE, Berkman LF, Gulanski BI, Robbins RJ, Greenspan SL, Charpentier PA, et al. Self-esteem and neuroendocrine response to challenge: MacArthur studies of successful aging. J Psychosom Res 1995;39:69-84.

92. Zorrilla EP, DeRubeis RJ, Redei E. High self-esteem, hardiness and affective stability are associated with higher basal pituitary-adrenal hormone levels. Psychoneuroendocrinology 1995;20:591-601.

93. Bartone PT, Valdes JJ, Sandvik A. Psychological hardiness predicts cardiovascular health. Psychol Health Med 2016;21:743-749.

94. Kirschbaum C, Prussner JC, Stone AA, Federenko I, Gaab J, Lintz D, et al. Persistent high cortisol responses to repeated psychological stress in a subpopulation of healthy men. Psychosom Med 1995;57:468-474.

95. Brandtstädter J, Baltes-Götz B, Kirschbaum C, Hellhammer D. Developmental and personality correlates of adrenocortical activity as indexed by salivary cortisol: observations in the age range of 35 to 65 years. J Psychosom Res 1991;35:173-185.

96. Grossi G, Åhs A, Lundberg U. Psychological correlates of salivary cortisol secretion among unemployed men and women. Integr Physiol Behav Sci 1998;33:249-263.

97. Smith TW, Glazer K, Ruiz JM, et al. Hostility, anger, aggressiveness, and coronary heart disease: An interpersonal perspective on personality, emotion, and health. J Pers 2004;72:1217-1270.

98. Lehmann J, Tennigkeit M, Haschke R, Haschke W, Rosahl S. Differences in mental task performance and slow potential shifts in subjects differing in cortisol level. Int J Psychophysiol 1992;13:1-8.

99. Taylor SE, Burklund LJ, Eisenberger NI, Lehman BJ, Hilmert CJ, Lieberman MD. Neural bases of moderation of cortisol stress responses by psychosocial resources. J Pers Soc Psychol 2008;95:197-211.

100. van Santen A, Vreeburg SA, Van der Does AW, Spinhoven P, Zitman FG, Penninx BW. Psychological traits and the cortisol awakening response: results from the Netherlands Study of Depression and Anxiety. Psychoneuroendocrinology 2011;36:240-248.

101. Sadegh-Nejadi S, Afrisham R, Soliemanifar O, Kooti W, Aberomand M, Najjar-Asl S, et al. Alteration of the level of salivary cortisol under psychological stress and its relationship with rumination and personality traits. J Gorgan Univ Med Sci 2017;19.

102. Roger D, Nesshoever W. The construction and preliminary validation of a scale for measuring emotional control. Pers Individ Dif 1987;8:527-534.

103. Traue HC, Kessler H, Deighton RM. Chapter 28-Emotional Inhibition A2-Fink, George. In: Fink G, Editor. Handbook of Stress: Concepts, 
Cognition, Emotion, and Behavior. 1st Edition. San Diego: Academic Press; 2016, p.262-263.

104. Kaiser J, Hinton JW, Krohne HW, Stewart R, Burton R. Coping dispositions and physiological recovery from a speech preparation stressor. Pers Individ Dif 1995;19:1-11.

105. Brosschot JF, Thayer JF. Anger inhibition, cardiovascular recovery, and vagal function: A model of the link between hostility and cardiovascular disease. Ann Behav Med 1998;20:326-332.

106. Gross JJ, Levenson RW. Hiding feelings: the acute effects of inhibiting negative and positive emotion. J Abnorm Psychol 1997;106:95-103.

107. Roger D, Jamieson J. Individual differences in delayed heart-rate recovery following stress: the role of extraversion, neuroticism and emotional control. Pers Individ Dif 1988;9:721-726.

108. Zoccola PM, Dickerson SS. Assessing the relationship between rumination and cortisol: a review. J PsychosomRes2012;73:1-9.

109. Gianferante D, Thoma MV, Hanlin L, Chen X, Breines JG, Zoccola $\mathrm{PM}$, et al. Post-stress rumination predicts HPA axis responses to repeated acute stress. Psychoneuroendocrinology 2014;49:244-252.

110. Zoccola PM, Quas JA, Yim IS. Salivary cortisol responses to a psychosocial laboratory stressor and later verbal recall of the stressor: the role of trait and state rumination. Stress 2010;13:435-443.

111. Brosschot JF, Gerin W, Thayer JF. The perseverative cognition hypothesis: A review of worry, prolonged stress-related physiological activation, and health. J Psychosom Res 2006;60:113-124.

112. Young EA, Nolen-Hoeksema S. Effect of ruminations on the saliva cortisol response to a social stressor. Psychoneuroendocrinology 2001; 26:319-329.

113. Zoccola PM, Dickerson SS, Yim IS. Trait and state perseverative cognition and the cortisol awakening response. Psychoneuroendocrinology 2011;36:592-595.

114. Byrd-Craven J, Granger DA, Auer BJ. Stress reactivity to co-rumination in young women's friendships: Cortisol, alpha-amylase, and negative affect focus. J Soc Pers Relat 2011;28:469-487.

115. Roberts BW, Jackson JJ. Sociogenomic personality psychology. J Pers 2008;76:1523-1544

116. Eysenck HJ. Dimensions of Personality. In: Strelau J, Angleitner A, Editors. Explorations in Temperament. Perspectives on Individual Differences. 1st Edition. Boston, MA: Springer, 1991, p.87-103.

117. Stelmack RM. Biological bases of extraversion psychophysiological evidence. J Pers 1990;58:293-311.

118. Schaefer M, Heinze HJ, Rotte M. Touch and personality: extraversion predicts somatosensory brain response. Neuroimage 2012;62:432-438.

119. Smith SL. Extraversion and sensory threshold. Psychophysiology 1968;5:293-299.

120. Killgore WD, Richards JM, Killgore DB, Kamimori GH, Balkin TJ. The trait of Introversion-Extraversion predicts vulnerability to sleep deprivation. J Sleep Res 2007;16:354-363.

121. Fried R, Fried B. Cardiac activity in a simple reaction time task. Integr Physiol Behav Sci 1981;16:151-156.

122. Siddle DA, Morrish RB, White KD, Mangan G. Relation of visual sensitivity to extraversion. J Exp Res Pers 1969; 3: 264-267..

123. Edman G, Schalling D, Rissler A. Interaction effects of extraversion and neuroticism on detection thresholds. Biol Psychol1979;9:41-47.

124. Mitchell RL, Kumari V. Hans Eysenck's interface between the brain and personality: Modern evidence on the cognitive neuroscience of personality. Pers Individ Dif 2016;103:74-81.

125. Claridge GS, Birchall PM. The biological basis of psychoticism: a study of individual differences in response to dexamphetamine. Biol Psychol 1973;1:125-137.

126. Claridge GS, Chappa HJ. Psychoticism: a study of its biological basis in normal subjects. Br J Clin Psychol 1973;12:175-187.

127. Loehlin JC, Medland SE, Montgomery GW, Martin NG. Eysenck's Psychoticism and the X-linked androgen receptor gene CAG polymorphism in additional Australian samples. Pers Individ Dif 2005; 39:661-667.
128. Turakulov R, Jorm AF, Jacomb PA, Tan X, Easteal S. Association of dopamine- $\beta$ - hydroxylase and androgen receptor gene polymorphisms with Eysenck's $P$ and other personality traits. Pers Individ Dif 2004;37:191-202.

129. Kirschbaum C, Bartussek D, Strasburger C. Cortisol responses to psychological stress and correlations with personality traits. Pers Individ Dif 1992;13:1353-1357.

130. Schommer N, Kudielka B, Hellhammer D, Kirschbaum C. No evidence for a close relationship between personality traits and circadian cortisol rhythm or a single cortisol stress response. Psychol Rep 1999; 84:840-842.

131. Arnetz BB, Fjellner B. Psychological predictors of neuroendocrine responses to mental stress. J Psychosom Res 1986;30:297-305.

132. Kennedy DK, Hughes BM. The optimism-neuroticism question: An evaluation based on cardiovascular reactivity in female college students. Psychol Record 2004;54:373-386.

133. Ferguson E. Health anxiety moderates the daytime cortisol slope. J Psychosom Res 2008;64:487-494.

134. Phillips AC, Carroll D, Burns VE, Drayson M. Neuroticism, cortisol reactivity, and antibody response to vaccination. Psychophysiology 2005;42:232-238.

135. McCleery JM, Goodwin GM. High and low neuroticism predict different cortisol responses to the combined dexamethasone-CRH test. Biol Psychiatry 2001;49:410-415.

136. Senior C, Loveday C. A pilot investigation into the neuroendocrine correlates of personality in the workplace. Percept Motor Skills 1998; 87:794.

137. Bouchard TJ, Loehlin JC. Genes, evolution, and personality. Behav Genet 2001;31:243-273.

138. Wiggins JS, Trapnell PD. Chapter 28-Personality Structure: The Return of the Big Five A2-Hogan, Robert. In: Johnson J, Briggs S, Editors. Handbook of Personality Psychology. 1st Edition. San Diego: Academic Press, 1997, p.737-765.

139. Yamagata S, Suzuki A, Ando J, Ono Y, Kijima N, Yoshimura K, et al. Is the genetic structure of human personality universal? A cross-cultural twin study from North America, Europe, and Asia. J Pers Soc Psychol 2006;90:987-998.

140. McCrae RR, Costa Jr PT. Personality trait structure as a human universal. Am Psychol 1997;52:509-516.

141. Rolland JP. The Cross-Cultural Generalizability of the Five-Factor Model of Personality. In: McCrae RR, Allik J, Editors. The Five-Factor Model of Personality Across Cultures. 1st edition. Boston, MA: Springer, 2002, p.7-28.

142. Gurven M, Von Rueden C, Massenkoff M, Kaplan H, Lero Vie M. How universal is the Big Five? Testing the five-factor model of personality variation among forager-farmers in the Bolivian Amazon. J Pers Soc Psychol 2013;104:354-370.

143. Buss DM. How can evolutionary psychology successfully explain personality and individual differences? Perspect Psychol Sci 2009;4:359366.

144. Vickers Jr RR. Stress Reactivity: Five-Factor Representation of a Psychobiological Typology. SanDiego, CA: Naval Health Research Center; 1991.

145. Hartmann P. The Five-Factor Model: Psychometric, biological and practical perspectives. Nord Psychology 2006;58:150-170.

146. Ouanes S, Castelao E, von Gunten A, Vidal M, Preisig M, Popp J. Personality, cortisol, and cognition in non-demented elderly subjects: results from a population-based study. Front Aging Neurosci 2017;9.

147. Houtman IL, Bakker FC. Individual differences in reactivity to and coping with the stress of lecturing. J Psychosom Res 1991;35:11-24.

148. Russell WM. Leadership Skills and Stress (Doctoral dissertation). Industrial/Organizational Psychology. San Angelo, Texas: Angelo State University; 2017.

149. Agrigoroaei S, Polito M, Lachman M. Individual differences in stress reactivity: The role of personality. 12th Annual Meeting of the Society 
for Personality and Social Psychology at San Antonio, Texas. Available at: http://www. brandeis.edu/departments/psych/lachman/pdfs/SPSP. 202011. 2011. Accessed June 19, 2017.

150. Nater UM, Hoppmann C, Klumb PL. Neuroticism and conscientiousness are associated with cortisol diurnal profiles in adults-role of positive and negative affect. Psychoneuroendocrinology 2010;35:1573-1577.

151. Zobel A, Barkow K, Schulze-Rauschenbach S, Von Widdern O, Metten M, Pfeiffer U, et al. High neuroticism and depressive temperament are associated with dysfunctional regulation of the hypothalamic-pituitary-adrenocortical system in healthy volunteers. Acta Psychiatr Scand 2004;109:392-399.

152. Schwebel DC, Suls J. Cardiovascular reactivity and neuroticism: Results from a laboratory and controlled ambulatory stress protocol. J Pers 1999;67:67-92.

153. Jonassaint C, Why Y, Bishop G, Tong EM, Diong SM, Enkelmann HC, et al. The effects of neuroticism and extraversion on cardiovascular reactivity during a mental and an emotional stress task. Int J Psychophysiol 2009;74:274-279.

154. Evans BE, Stam J, Huizink AC, Willemen AM, Westenberg PM, Branje $\mathrm{S}$, et al. Neuroticism and extraversion in relation to physiological stress reactivity during adolescence. Biol Psychol 2016;117:67-79.

155. Oswald LM, Zandi P, Nestadt G, Potash JB, Kalaydjian AE, Wand GS. Relationship between cortisol responses to stress and personality. Neuropsychopharmacology 2006;31:1583-1591.

156. Miller GE, Cohen S, Rabin BS, Skoner DP, Doyle WJ. Personality and tonic cardiovascular, neuroendocrine, and immune parameters. Brain Behav Immun 1999;13:109-123.

157. Chu X, Ma Z, Li Y, Han J. Agreeableness, extraversion, stressor and physiological stress response. Intl J Soc Sci Stud 2015;3:79-86.

158. Vickers Jr RR, Hervig LH, Poth M, Hackney AC. Cortisol Secretion
Under Stress: Test of a Stress Reactivity Model in Young Adult Males. San Diego, CA: Naval Health Research Center; 1995.

159. Tops M, Boksem MA, Wester AE, Lorist MM, Meijman TF. Task engagement and the relationships between the error-related negativity, agreeableness, behavioral shame proneness and cortisol. Psychoneuroendocrinology 2006;31:847-858.

160. Parent-Lamarche A, Marchand A. The moderating role of personality traits in the relationship between work and salivary cortisol: a crosssectional study of 401 employees in 34 Canadian companies. BMC Psychol 2015;3:45.

161. Bogg T, Slatcher RB. Activity mediates conscientiousness' relationship to diurnal cortisol slope in a national sample. Health Psychol 2015; 34:1195-1199.

162. Laceulle OM, Nederhof E, van Aken MA, Ormel J. Adolescent personality: Associations with basal, awakening, and stress-induced cortisol responses. J Pers 2015;83:262-273.

163. Steptoe A, Easterlin E, Kirschbaum C. Conscientiousness, hair cortisol concentration, and health behaviour in older men and women. Psychoneuroendocrinology 2017;86:122-127.

164. Gartland NK. Conscientiousness and Daily Stress: Exploring the Effects on Cortisol and Health Outcomes. Thesis (Ph.D.) Leeds, UK: University of Leeds; 2012.

165. Sher L. Type D personality: the heart, stress, and cortisol. QJM 2005; 98:323-329.

166. Monasterio E, Mei-Dan O, Hackney AC, Lane AR, Zwir I, Rozsa S, et al. Stress reactivity and personality in extreme sport athletes: The psychobiology of BASE jumpers. Physiol Behav 2016;167:289-297.

167. Perugula M, Narang P, Lippmann S. The Biological Basis to Personality Disorders. Prim Care Companion CNS Disord 2017;19. 